\title{
Attributes Affecting the Level of Tourist Satisfaction with and Loyalty towards Theatrical Performance in China: Evidence from a Qualitative Study
}

\author{
Hanqun Song \\ $\&$ \\ Catherine Cheung
}

School of Hotel and Tourism Management,

The Hong Kong Polytechnic University

Accepted by International Journal of Tourism Research

\begin{abstract}
This study seeks to explore attributes affecting the level of tourist satisfaction with and loyalty towards theatrical performance in China. Based on four focus group discussions with 31 participants, the study identifies 34 attributes that affect the level of tourist satisfaction with theatrical performance, and groups them into five categories: stage, performance, venue, service, and tourist-related attributes. The findings on tourist loyalty reveal that most of the respondents would not watch the same theatrical performance alone in the future; however, they would recommend it to others. The study concludes with a discussion of the rich and insightful findings and their implications for tourism industry practitioners.
\end{abstract}

Keywords: Theatrical performance; tourist satisfaction; tourist loyalty; qualitative method; China 


\section{INTRODUCTION}

China's tourism industry has developed rapidly in the three decades since the implementation of the open-door policy in 1978, as reflected in the increasing number of domestic and international tourist arrivals (WTTC, 2004). In the early stage of the tourism industry in China, there were only a few kinds of tourism activities and entertainment. A Chinese saying sums up the itinerary - "daytime activity for tourists is visiting temples, nighttime activity is sleeping." However, with the enormous growth in the tourism industry, the number and types of tourism activities have increased dramatically, especially in tourism entertainment. Tourism entertainment can not only enhance the tourist experience but also improve destination competitiveness (Xin Jing News, 2008).

There are many types of tourism entertainment in the tourism industry. Pearce (2008) defined tourism entertainment as structured and managed situations designed for a predominantly visitor audience, which include cultural shows, dance performances, theme park presentations, fun guided tours, and film and video presentations tailored exclusively for visitors. In China, theatrical performance, a type of tourism entertainment, can be divided into many types based on various criteria. It can showcase the local culture, the culture of ethnic minorities, or traditional Chinese culture. Small live performances feature one or two performers, whereas large-scale live performances involve from one hundred to more than three hundred performers. The former may be short fifteen-minute shows, whereas the latter normally last from one to two hours. Some live shows are performed outdoors near hills, rivers, or lakes. Examples include The Impression of Liusanjie, The Impression of Lijiang, The Impression of West Lake, The Song of Eternal Sorrow, and Zen Music Shaolin Grand Ceremony. Indoor performances of well-known productions that are staged in a theater include The Romance of the Song Dynasty, The Night of West Lake, and The Legend of Kung Fu.

In 2008, 300 large-scale theatrical performances in China generated more than RMB3 billion in tourism income (Xin Jing News, 2008). Theatrical performance has become a major tourist attraction in China (Xu, 1998), and more and more cities are presenting theatrical performances to visitors. Almost every major city in China now stages theatrical productions following the success of The Impression of Liusanjie at Guilin in 2003 (Zhuge and Cui, 2005). Nevertheless, only a small number of tourism studies have investigated theatrical performance in China. Li, Zhang, Lu, Wen and Wang (2005) studied the production system of tourist-directed performing arts using a theme park in Shenzhen Overseas Chinese Town as a case study. Tian and Bao (2005) did an authenticity study of cultural performances of the Dai minority in Xishuangbanna.

In China, theatrical performance is a product of the culture and tourism industries. China's Ministry of Culture and National Tourism Administration highly encourage the entrance of the performing arts into the tourism industry, and promote the development of theatrical performance (Central People's Government of the People's Republic of China, 2009). Theatrical performance combines the performing arts with high-technology facilities, and in some cases, beautiful natural surroundings (Shanghai Daily, 2006). It is 
developing at a fast pace. In 2007 alone, around RMB179 million was invested in theatrical productions that involved 17.6 thousand professional and amateur performers and 167 million audience members (X. Wei, 2007). The investment in theatrical performance is huge. For instance, in 1998, the production cost of The Romance of the Song Dynasty was RMB60 million (Jiang, 2006), in 2003, The Impression of Liusanjie cost RMB70 million (F. Wei, 2007), and in 2006, The Impression of Lijiang had a budget of US\$31 million, while Zen Music Shaolin Grand Ceremony cost US\$12.5 million (Shanghai Daily, 2006). Theatrical performance also has an economic impact on the local tourism industry. The Impression of Liusanjie, for example, increased the gross domestic product (GDP) of Yangshuo County in Guilin by more than 10\%, and increased the length of stay of tourists in the County by eight hours per person (Wang, 2008).

The goal of theatrical performance of a destination is to boost the local tourism industry, whereas that of stakeholders is profitability. In previous studies, consumer satisfaction has been linked to higher business profits through loyalty (Alegre and Juaneda, 2006; Gupta, McLaughlin and Gomez, 2007). Hence, there is an urgent need to study tourist satisfaction with and loyalty towards theatrical performance in China. However, such studies are scarce. To fill this research gap, the study aims to explore the attributes affecting the level of tourist satisfaction with, and to determine whether there is tourist loyalty towards, theatrical performance in China.

\section{LITERATURE REVIEW}

\section{Tourism entertainment}

The literature related to theatrical performance is rooted in the tourism entertainment research. According to Hughes (2000), entertainment includes live performances of music, dance, shows, and plays, going to the cinemas, clubs, discos, and sport matches, watching television, playing computer games, and listening to CDs. Hughes and Allen (2008) defined entertainment as live performances of plays, music, dance, and the like that are different from the fine arts as experienced in developed, long-established tourist destinations. Pearce (2008) identified common and noteworthy characteristics of tourism entertainment from a range of micro-cases, and defined tourism entertainment as structured and managed situations designed for a predominantly visitor audience. Ryan and Collins (2008) were the first to analyze the construction of theater entertainment with their examination of An Eastern Odyssey in Japan. They stated that within a trilogy of fantasies, production, the nature of Huis Ten Bosch (a theme park in Nagasaki Prefecture that recreates the Netherlands), and a financial fantasy, An Eastern Odyssey becomes itself a metaphor for much post-modern tourism (Ryan and Collins, 2008). Most studies of tourism entertainment consider one instance of the phenomenon, and approach that setting with one guiding set of ideas (Harris 2005; Prentice 2003).

\section{Theatrical performance}

One definition of theatrical performance is "a performance of a play." 1 In the present study, theatrical performance refers to large-scale live performances staged indoors or 
outdoors, that are predominantly designed for tourists. Chen, Bai, Qiao and Park (2008) analyzed inbound tourist satisfaction and future revisit intention regarding a theatrical production, Zen Music Shaolin Grand Ceremony, a traditional cultural product, based on three intangible factors: traditional, education, and fascination. They found a significant relationship between the three factors and tourist satisfaction and revisit intention, respectively. However, little is found about the attributes of theatrical performances in the tourism research. Some useful studies are found in the hospitality field. For instance, Hede, Jago and Derry (2004) measured eight attributes of a theater event, "storyline," "stage work," "costumes," "acting and singing," "ambience of the theater," "service at the theater," "value for money," and "vision from the seats," to test a conceptual framework that included personal values, satisfaction, and post-consumption behavioral intentions. They found that with the exception of "vision from the seats," these attributes were significantly related with tourist satisfaction.

\section{Tourist satisfaction}

Tourist satisfaction is defined as post-consumption evaluation concerning a specific product or service (Westbrook and Oliver, 1991), and proposed to be one of the key judgments that tourists make regarding a tourism service. Hence, it is a well-established, long-standing focus marketer attention (Yuksel and Yuksel, 2002).

There are many tourism and hospitality studies of the factors affecting the level of tourist satisfaction. In the tourism research investigating destination, Chi and Qu (2008) chose 33 destination items to measure tourist satisfaction, and distinguished seven key factors: lodging, dining, shopping, attractions, activities and events, environment, and accessibility. Master and Prideaux (2000) selected eight attributes to assess Taiwanese tourist satisfaction in South East Queensland. Heung and Qu (2000) examined the satisfaction levels of Japanese tourists to Hong Kong in terms of 31 travel attributes. Mazanec (2006) studied tourist satisfaction with ski resorts using six satisfaction indicators: ease of access, situation at ticket selling points, level and variety of prices, cableways and ski lifts, skiing area, skiing runs, services, and restaurants. In the hospitality research, Yuksel and Yuksel (2002) investigated restaurant selection and foodservice evaluation by measuring the level of tourist satisfaction with dining based on 10 factors: service quality, product quality, menu diversity, hygiene, convenience and location, noise, service speed, price and value, facilities, and atmosphere.

\section{Tourist loyalty}

Tourist loyalty is commonly measured by three indicators: intention to continue buying the same product, intention to buy more of the same product, and willingness to recommend the product to others (Hepworth and Mateus, 1994). However, various tourism products have different loyalty measurements. Chen and Gursoy (2001) used inclination to use the same airline and stay in the same franchised hotel whenever traveling to measure tourist loyalty, and willingness to recommend the product to others to measure tourist loyalty towards a destination. However, other studies have chosen two indicators to measure destination loyalty, such as tourist intention to revisit the 
destination and willingness to recommend it to others as a favorable destination (Chi and Qu, 2008).

In the theatrical performance research, Chen et al. (2008) measured tourist loyalty towards theatrical performance using two indicators: would you recommend the theatrical performance you have seen to your friends and relatives, and would you watch the same theatrical performance in the future? They found that inbound tourists were willing to revisit the same theatrical performance and to recommend it to others. Petrick, Morais and Norman (2001) examined tourist intention to revisit an entertainment destination, live theater entertainment, and take advantage of an entertainment package again, and found that past behavior, satisfaction, and perceived value are not good predictors of intention to revisit live theater entertainment.

\section{METHODOLOGY}

Because of the lack of theatrical performance-specific research in the tourism literature, this study tried to gain detailed information and uncover issues related to this topic for discussion in future research (Cole, 2004). To meet these goals, it used a qualitative method - focus group discussion. Open-ended questions were used in the focus group discussions, as they can reveal the world as seen by respondents and capture the points of view of other people through prior selection of questionnaire categories (Patton, 2002). Four focus group discussions, with a total of 31 participants, were held in Hong Kong and Shenzhen in February 2009. Focus group members were recruited from universities and the community. E-mail invitations were sent to the mainland Chinese students studying at the School of Hotel and Tourism Management in Hong Kong, and participants were directly recruited from a course with a large number of students at Shenzhen University in China. Group members were also recruited by poster advertisements from a community in Shenzhen. All participants in the focus groups were screened to ensure that they had watched at least one theatrical performance in China in the past 12 months. The researcher facilitated and mediated every session. An assistant helped to distribute the open-ended questions, took notes, and recorded the discussions. The researcher first explained the definition of theatrical performance being used in this study. Then, four open-ended questions stimulated the discussion among participants. Finally, participants were asked to provide demographic information.

The open-ended questions used in the discussions are as follows.

1. What kind of stage attributes affected the level of your satisfaction with the theatrical performance that you saw in China?

2. What other attributes do you think affected the level of your satisfaction?

3. Would you watch the same theatrical performance in the future? Why or why not?

4. Would you recommend the theatrical performance that you saw to others? Why or why not?

Data coding and analysis of the audio recordings and notes of the discussions were 
carried out by the researcher to develop a categorization scheme. The resulting categories were then reviewed by another researcher, and several minor modifications were made. Direct quotations from the focus group participants were used in the data analysis and are included in the Findings session as they demonstrate the depth of emotion, thoughts, experiences, and perceptions of the participants (Patton, 2002), and provide a trail of evidence to support the categorization scheme.

\section{FINDINGS}

\section{Profile of the participants}

A total of 31 people, all mainland Chinese, participated in the four focus group discussions. The Group 1 and 2 discussions were conducted in Hong Kong, while the Group 3 and 4 discussions were conducted in Shenzhen. The demographic characteristics of the participants are presented in Table 1.

*****Please insert Table 1 here*****

Nineteen females and twelve males participated in the study. The majority (90\%) of participants was aged between 20 to 30 years old, and there were also more single than married interviewees. Among the 31 participants, 12 were students. Most of the participants had a higher educational degree. One third respondents, full-time students, had no income (10), followed by those with an unstable income (7) and those with a monthly income of more than RMB5, 000 (7). Seventeen respondents were in families of 2-3 persons, and twelve were in families of 4-5 persons.

\section{Tourist satisfaction and attributes affecting the level of tourist satisfaction with theatrical performance in China}

Almost all of the focus group participants said that they were satisfied with the performance they had seen. Most reported a very high level of satisfaction. Experiencing a theatrical performance, an innovative tourism product, was perceived by respondents to be a valuable opportunity to enjoy fantastic scenery and culture, amazing performing arts, and high-technology effects.

Analysis of the audio recordings and researcher's notes from the focus group discussions yielded 34 attributes affecting the level of tourist satisfaction with theatrical performance. In order to sustain an order of categorization, these attributes were then divided into five categories: stage, performance, venue, service, and tourist-related attributes (see Figure 1). It should be noted that the five categories are analytically developed by the researchers, and they are not wholly independent and relationships exist among them.

$* * * * *$ Please insert Figure 1 here*****

\section{Stage attributes}


Stage attributes are items associated with stage facilities and equipments. Hede et al. (2004) assessed tourist satisfaction with theater events based on three attributes, "costumes," "acting and singing," and "stage work," and found a significant relationship between each of these and tourist satisfaction. However, the three attributes are general features of theater events. Therefore, the current study considered nine attributes: "costumes," "stage decorations," "background scenery or screen," "scale of the stage," "water and a waterfall on the stage," "smoke," "lighting," "music and songs," and "loud sounds."

The nine attributes provide a detailed picture of the stage facilities and the hightechnology effects incorporated into the performance. Most of the respondents mentioned that these tangible stage-related attributes played a great role in the level of their satisfaction, as these features drew their attention to the stage and the show being performed. Regarding common stage facilities, namely, "costumes of the performers," "stage decoration," "background scenery or screen," and "scale of the stage," most respondents said that these could have been better, which resulted in lower levels of satisfaction with the performance. However, most participants said that the hightechnology effects, including "water and a waterfall on the stage," "smoke," and "lighting," exceeded their expectations. They were very surprised when they first saw these effects. Some respondents mentioned that the beautiful music and songs really impressed them. However, some said that the loud sounds made them uncomfortable. The stage items and related quotations drawn from the focus group discussions are presented in Table 2.

*****Please insert Table 2 here*****

\section{Performance attributes}

Performance attributes concern both the performance and performers. Hede et al. (2004) found that storyline had a significant relationship with tourist satisfaction in the theaterevent context. This study considered seven performance attributes: "performance is special and unique," "professional performers," "good coordination among performers," "performers show emotion," "performers show enthusiasm," "good order of performance," and "punctual start of performance."

Many respondents mentioned that they prefer a unique and special performance. They appreciated a unique storyline or new kind of production. The Impression of Liusanjie, for example, was staged outdoors in a natural environment, unlike other productions. "Professional performers," "good coordination among performers," "performers show emotion," and "performers show enthusiasm" were other attributes mentioned by the respondents, who were moved by the facial expressions and acting of the performers. "Good order of performance" was also important, as respondents noted that every part of the performance should proceed in proper order. A punctual start was also important to the participants, who preferred a performance to start on time so that they did not have to wait for a long time. Performance items and related quotations are given in Table 3. 
*****Please insert Table 3 here*****

\section{Venue attributes}

Venue attributes can also affect the level of tourist satisfaction. Hede et al. (2004) used "ambience of the theater" and "vision from the seats" to assess the level of tourist satisfaction with theater events, and find a statistically significant relationship between "ambience of the theater" and level of tourist satisfaction, but no such relationship between "vision from the seats" and level of tourist satisfaction. The current study considered eleven venue attributes: "cleanliness of the venue," "comfortable seating," "vision of the performance," "clean air," "moderate temperature in the venue," "safety and security of the venue," "behavior of other audience members," "suitable audience number in the venue," "accessibility of the venue," "location of the venue," and "weather."

The attributes of the venue at which the performance was staged had a significant effect on the focus group members. "Ambience of the venue" has been found to influence tourist satisfaction in not only the theater (Hede, et al., 2004) but also the destination (Chi and Qu, 2008; Swarbrooke and Horner, 1999) context. Other attributes affected the enjoyment of participants of the performance, including "comfortable seating," "vision of the performance," "clean air," and "moderate temperature in the venue." Many respondents also mentioned "safety and security of the venue," consistent with tourism studies such as that of Chi and Qu (2008), who found safety and security factors to be an immediate antecedent of satisfaction with the venue and to contribute indirectly to overall satisfaction. "Behavior of other audience members" has been confirmed to be a factor influencing customer satisfaction in various tourism contexts, especially destination (Swarbrooke and Horner, 1999), while in the restaurant context, "suitable number in the venue" has been found to directly affect the level of the quality of hospitality service and indirectly affect the level of tourist satisfaction (Yuksel and Yuksel, 2002).

"Accessibility of theatrical performance" and "location of venue" were found to be factors affecting the level of participants' satisfaction with theatrical performance in China. Many theatrical performances were put on in remote areas and most were staged at night, so accessibility was a big problem. Many focus group members felt unsafe when returning to their hotels. The destination literature has also found that accessibility is a factor affecting the level of tourist satisfaction (Chi and Qu 2008; Swarbrooke and Horner, 1999).

Previously, large-scale theatrical performances were only staged indoors in independent or in tourist theaters. In 2003, a new type of theatrical performance was presented in Guilin by Chinese director Zhang Yimou, The Impression of Liusanjie, which played outdoors on an open river surrounded by hills. Since then, many theatrical performances have been put on outdoors, including The Impression of Lijiang, The Impression of West Lake, Zen Music Shaolin Grand Ceremony, and The Song of Eternal Sorrow. Outdoor productions can be greatly affected by bad weather, and cancelled because of heavy rains or thick fog. Tourists are unwilling to brave the cold weather or 
heavy rains, as most watch the performance unprotected from the elements (VIP tourists are exception). "Weather" is an uncontrollable factor that has been found to affect the level of customer satisfaction in the destination domain (Swarbrooke and Horner, 1999). Venue items and related quotations are presented in Table 4.

$$
* * * * * \text { Please insert Table } 4 \text { here } * * * * *
$$

\section{Service attributes}

Service attributes are service factors affecting the level of tourist satisfaction with theatrical performance. Many tourism and hospitality studies indicate that service quality is an antecedent of satisfaction, and find a clear and significant relationship between service quality and tourist satisfaction (Ekinci, 2004; Hede et al., 2004; Rust and Oliver, 1994). In this study, "service quality," "ticket price/value for money," "performances are staged at night," "suitable duration of the performance," and "sale activities related to the performance" were found to affect the level of satisfaction of participants.

"Service quality" in the theatrical performance context extended from the ticket office service to the services offered at the venue. Friendly and competent staffs affect the viewing experience and emotions of tourists. "Ticket price/value for money" also affected the level of tourist satisfaction. Perceived price fairness is defined as the perception of the price by consumers as reasonable, acceptable, and just (Bolton, Warlop and Alba, 2003), and is found to be positively related to customer satisfaction and loyalty (Bei and Chiao, 2001).

In China, most theatrical performances are put on at night, which enriches the nightlife of tourists by providing them with a chance to relax and experience the local culture. However, some respondents did not want to see a night-time performance, as they needed to wait for a long time before it would start. Some respondents also mentioned that they did not want to see a performance of great duration; they just wanted to relax. Therefore, "suitable duration of the performance" was important, especially for productions staged at night.

"Sale activities related to the performance" also affected the level of tourist satisfaction. Some respondents said that they did not care for such activities, but that these activities took place before the performance started. They said that such activities were annoying, and some were even organized by the theater operators. Service items and related quotations are presented in Table 5.

$$
* * * * * \text { Please insert Table } 5 \text { here } * * * * *
$$

\section{Tourist-related attributes}

There are both intrinsic and extrinsic tourist-related attributes. In the current study, the focus group participants mentioned that "tourist understanding of the culture being showcased through the performance" (intrinsic attributes) and "tourist companions" 
(extrinsic attributes) affected their level of satisfaction. The different attitudes, standards and prejudice of tourists affect the level of their satisfaction; their satisfaction, or otherwise, is based on subjective views about an issue that is important to them, and which they judge in their own way (Swarbrooke and Horner, 1999). Cross-cultural studies suggest that cultural values result in different beliefs, perceptions, and behaviors (Ajzen and Fishbein, 1980). Li, Lai, Chick, Zinn and Graefe (2007) found a positive relationship between culture and level of satisfaction. In the present study, the participants mentioned that they could not understand the local culture. There are various local cultures and subcultures in different parts of China. People from east China seemed to have problems understanding the culture of ethnic minorities living in west China.

Some respondents also mentioned that their companions influenced the level of their satisfaction with the theatrical performance. Tourist-related items and related quotations are presented in Table 6.

*****Please insert Table 6 here*****

\section{Tourist loyalty towards theatrical performance in China}

In this study, almost all of the focus group participants said that they were satisfied with the theatrical performance that they had seen. However, they said that they would not watch the same theatrical performance alone in the future. The finding of tourist loyalty towards theatrical performance in this study is consistent with that of Petrick et al. (2001) that satisfaction is not a good predictor of intention to revisit with regard to live theater entertainment. However, Chen et al. (2008) found that inbound tourists were willing to watch the same theatrical performance in the future, and that intangible factors related to theatrical performance had a positive and significant effect on revisit intention. The different findings may be due to the different samples. The current study uses a small sample of domestic travelers, whereas that of Chen et al. (2008) used a sample of inbound tourists.

The respondents gave a number of reasons why they would not want to see the same theatrical performance in the future. First, most said that they would prefer to see a new theatrical performance rather than the same one. It should be noted that the content of some theatrical performances changes somewhat from time to time; however, there is little difference compared to the previous shows. Second, many respondents in Group 1, 2 , and 3 mentioned the high price of tickets as the main factor affecting their revisit intention, partly because they were price-sensitive tourists who were younger and earned less money than the participants in Group 4. Third, some Group 4 members noted that the feelings of their family members were the main factor affecting their revisit intention. If their family members liked the performance and it was not too far away from where they were staying, then they would be willing to see it again. Fourth, some respondents said that the great distance of the theatrical performance from the downtown area would deter them from watching the same performance in the future. Finally, many mentioned that the theatrical performance was not the main attraction of the destination, and that they usually plan to see a performance after deciding on a specific destination or after they 
arrive at their destination.

Although most of the respondents would not watch the same theatrical performance alone in the future, they did not object to accompanying their friends or relatives to see it again, and were very likely to recommend what they had seen to others. The findings of this study are consistent with those of Chen et al. (2008) that tourists are willing to recommend the theatrical performance that they have seen to others, and that factors of the theatrical performance have a positive and significant relationship with recommendation intention.

Regarding why they would or would not recommend the shows that they had seen to others, the focus group members mentioned that they wanted their friends, relatives, and colleagues to enjoy the high-quality theatrical performance. They said that if they knew that their friends or relatives were planning to visit the destination at which they had seen the performance, they would recommend it to them, rather than directly recommending it to others, as most tourists do not visit a destination just to see a theatrical performance. In addition, some members said that the interests and hobbies of their friends and relatives were also a factor affecting whether they would recommend the show they had seen. That is, they would recommend it to those who might be interested in such an activity.

\section{DISCUSSION AND IMPLICATIONS}

The findings of this study can help theater operators to understand tourist satisfaction with loyalty towards theatrical performance in China. The results of the study reveal five categories of attributes affecting the level of tourist satisfaction: stage, performance, venue, service, and tourist-related attributes. Regarding stage and performance attributes, to be successful, a theatrical performance should have unique and special stage and performance-related elements. Therefore, the theme and content of theatrical performances should be based on the unique culture and attractions of a destination. Theatrical productions should incorporate the local culture, high-technology effects, and professional performers.

Venue and service quality factors are also of great importance to the level of tourist satisfaction. Some focus group participants with families said that the venue attributes were more important than either the stage or performance ones. They viewed a theatrical performance as an unforgettable event, comprising not just the theatrical performance product itself but the whole experience. Theater operators should focus on venue and service quality attributes, such as ticket price, the environment of the venue, services provided by staff, and security. Training for staff to improve service quality is needed to increase the level of tourist satisfaction with the whole theater experience. Theater operators should also maintain venue facilities to a high standard, and address security and seating issues. The value for money problem could be solved by the improvement of venue facilities and service quality. Meanwhile, regarding such problems as audience members speaking loudly and taking pictures during the performance, notices and announcements could be used to remind the audience to refrain from these practices. It should be emphasized that a successful theatrical performance does not depend on one 
attribute but rather an extensive number of them, including those in five categories identified herein.

Implications for theater operators in terms of tourist loyalty towards theatrical performance include the following. To enhance the attractiveness of the theatrical performances held at a specific destination, marketing strategies linking these productions and the destination should be implemented by theater operators and local governments. Tourists could recommend a theatrical performance to others based on the attractiveness of the destination. Marketing promotions highlighting improvements in venue accessibility and changes in theatrical content could also attract more repeat visitors.

\section{CONCLUSION AND LIMITATIONS}

This exploratory study addresses the gap in knowledge about tourist satisfaction and loyalty related to theatrical performance in China. Based on four focus group discussions with 31 participants, this study identifies 34 attributes that affect the level of tourist satisfaction with theatrical performance, and groups these into five categories: stage, performance, venue, service, and tourist-related attributes. The findings on tourist loyalty reveal that most of the respondents would not watch the same theatrical performance alone in the future; however, they would recommend it to others. The article also provides a discussion of the rich and insightful findings and their implications for tourism industry practitioners.

This study has some limitations. First, it focuses on large-scale theatrical performance in China. Hence, the findings are not generalizable to all types of theatrical performance. Second, all of the focus group participants are mainland Chinese, who have been recruited from a community in Shenzhen and from universities in Shenzhen and Hong Kong. Further, the sample is limited to two Chinese cities; however, the target market of some theatrical performances is international tourists. Third, a qualitative method alone is insufficient to assess tourist satisfaction and loyalty. Therefore, future research should use a quantitative method to test and confirm the study findings.

Note:

${ }^{1}$ This definition of theatrical performance was retrieved 10 April 2009 from the World Wide Web: http://www.thefreedictionary.com 


\section{REFERENCES}

Ajzen I, Fishbein M. 1980. Understanding attitudes and predicting social behavior. Englewood Cliffs, NJ: Prentice Hall.

Alegre J, Juaneda C. 2006. Destination loyalty: Consumers' economic behavior. Annals of Tourism Research 33(3): 684-706.

Bei L, Chiao Y. 2001. An integrated model for the effects of perceived product, perceived service quality, and perceived price fairness on consumer satisfaction and loyalty. Journal of Consumer Satisfaction, Dissatisfaction and Complaining Behavior 14(1): 125-140.

Bolton L, Warlop L, Alba J. 2003. Consumer perceptions of price (un)fairness. Journal of Consumer Research 23(4): 474-491.

Central People's Government of the People's Republic of China. 2009. Guides and suggestions for the combination of culture industry and tourism industry from China Ministry of Culture and China National Tourism Administration. Available at: http://big5.gov.cn/gate/big5/www.gov.cn/zwgk/200909/15/content_1418269.htm (accessed September 2009).

Chen J, Gursoy D. 2001. An investigation of tourists' destination loyalty and preferences. International Journal of Contemporary Hospitality Management 13(2): 79-85.

Chen N, Bai K, Qiao G, Park K. 2008. A demonstrative study on inbound tourists' satisfaction with Chinese traditional cultural tourism product: A case on Zen Music Shaolin Grand Ceremony. Tourism Tribune 23(6): 24-29. (in Chinese)

Chi C, Qu H. 2008. Examining the structural relationships of destination image, tourist satisfaction and destination loyalty: An integrated approach. Tourism Management 29(4): 624-636.

Cole S. 2004. Shared benefits: Longitudinal research in eastern Indonesia. In Phillimore, $\mathrm{J}$, and Goodso, L (Eds.), Qualitative research in tourism: Ontologies, epistemologies, and methodologies. London: Routledge.

Ekinci Y. 2004. An investigation of the determinants of customer satisfaction. Tourism Analysis 8(2-4): 197-203.

Gupta S, McLaughlin E, Gomez M. 2007. Guest satisfaction and restaurant performance. Cornell Hotel and Restaurant Administration Quarterly 48(3): 284-298.

Harris D. 2005. Key concepts in leisure studies. London: Sage. 
Hede A, Jago L, Deery M. 2004. Segmentation of special event attendees using personal values: Relationships with satisfaction and behavioral intentions. Journal of Quality Assurance in Hospitality and Tourism 5(2/3/4): 33-55.

Hepworth M, Mateus P. 1994. Connecting customer loyalty to the bottom line. Canadian Business Review 21(4): 40-44.

Heung V, Qu H. 2000. Hong Kong as a travel destination: An analysis of Japanese tourists' satisfaction levels, and the likelihood of them recommending Hong Kong to others. Journal of Travel and Tourism Marketing 9(1/2): 57-80.

Hughes H. 2000. Arts, entertainment and tourism. Oxford: Butterworth Heinemann.

Hughes H, Allen D. 2008. Entertainment and its significance in the holiday experience at UK seaside resorts. Tourism Recreation Research 33(2): 131-141.

Jiang G. 2006. Some opinions on the business model of performances in the Song Dynasty Town. Journal of Zhejiang Vocational Academy of Art, 4(4): 106-113. (in Chinese)

Li C, Lai P, Chick G, Zinn H, Graefe A. 2007. Cross-cultural models of customer service: A case of county park. Journal of Park and Recreation Administration 25(3): 4166.

Li L, Zhang H, Lu J, Wen J, Wang X. 2005. The production mode of tourism performing art as a cultural industry: A case study of the theme park in Shenzhen Overseas Chinese Town. Tourism Science 19(6): 44-51. (in Chinese)

Mazanec J. 2006. Exploring tourist satisfaction with nonlinear structural equation modeling and inferred causation analysis. Journal of Travel and Tourism Marketing 21(4): 73-90.

Master H, Prideaux B. 2000. Culture and vacation satisfaction: A study of Taiwanese tourists in South East Queensland. Tourism Management 21(5): 445-449.

Patton M. 2002. Qualitative research and evaluation methods. Thousand Oaks, CA: Sage.

Pearce PL. 2008. Tourism and entertainment: Boundaries and connections. Tourism Recreation Research 33(2): 125-130.

Petrick JF, Morais DD, Norman WC. 2001. An examination of the determinants of entertainment vacationers' intentions to revisit. Journal of Travel Research 40(1): 41-48. 
Prentice R. 2003. Revisiting "Heritage: A key sector of the (then) 'new' tourism" - Out with the "new" and out with "heritage"? In Copper C (Ed.), Classic reviews in tourism, (pp.164-191), Clevedon: Channel View.

Ryan C, Collins AB. 2008. Entertaining international visitors: The hybrid nature of tourism shows. Tourism Recreation Research 33(2): 143-149.

Rust R, Oliver R. 1994. Service quality insights and managerial implications from the frontier. In Rust RT, Oliver R (Eds.), Service quality: New directions in theory and practice, (pp. 1-20), London: Sage.

Shanghai Daily. (2006, November 8). Open-air blockbusters: The future of Chinese theater? Available at: http://russian.china.org.cn/english/culture/188335.htm (accessed March 2009).

Swarbrooke J, Horner S. 1999. Consumer behavior in tourism. Oxford: ButterworthHeinemann.

Tian M, Bao J. 2005. Tourists' perspectives on the authenticity of ethnic performance: A case study of Dai minority in Xishuangbanna. Journal of Guilin Institute of Tourism 16(1): 12-19. (in Chinese)

Wang C. 2008. Insights from tourism marketing on outdoor theatrical performance: A case from The Impression of Liusanjie. Culture and History Vision (Theory) 49(1): 70-71. (in Chinese)

Wei F. 2007. Game theory on the tourism community residents and stakeholders: A case from the outdoor theatrical performance The Impression of Liusanjie. Study of Ethnics in Guangxi 23(3). (in Chinese)

Wei X. (2007, December 14). An review on tourism performance market in 2007. China Tourism News, 5-8. (in Chinese)

Westbrook RA, Oliver RL. 1991. The dimensionality of consumption emotion patterns and consumer satisfaction. Journal of Consumer Research 18(1): 84-91.

WTTC. 2004. The impact of travel and tourism on jobs and economy: China and China Hong Kong SAR, Special Country Report. World Travel and Tourism Council. Available at http://www.wtcc.org/frameset4.htm (accessed April 2009).

Xin Jing News. (2008, December 24). A review on tourism performing industry in China. Available at: http://www.ask.com/web?o=14159andl=disandvfr=1andq=www\%2Epeople\%2Ec om\%2Ecn (accessed March 2008).

Xu J. 1998. Review of conference on theme parks and performing arts in China. Tourism 
Tribune 13(5): 18-22. (in Chinese)

Yuksel A, Yuksel F. 2002. Measurement of tourist satisfaction with restaurant services: A segment-based approach. Journal of Vacation Marketing 9(1): 52-68.

Zhuge Y, Cui F. 2005. Research on tourism performing product refinement strategy in China. Social Scientist 115(5): 121-123. (in Chinese) 
Table 1: Profile of the focus group participants

\begin{tabular}{|c|c|c|c|c|c|}
\hline $\mathrm{N}=31$ & Group 1 & Group 2 & Group 3 & Group 4 & Total \\
\hline Gender & & & & & \\
\hline Male & 2 & 2 & 4 & 4 & 12 \\
\hline Female & 5 & 4 & 4 & 6 & 19 \\
\hline Age & & & & & \\
\hline $19-29$ & 5 & 5 & 8 & 1 & 19 \\
\hline 30-39 & 2 & 1 & & 5 & 8 \\
\hline $40-49$ & & & & 3 & 3 \\
\hline 50 or above & & & & 1 & 1 \\
\hline Marital status & & & & & \\
\hline Single & 4 & 5 & 7 & 1 & 17 \\
\hline Married & 3 & 1 & 1 & 9 & 14 \\
\hline Occupation & & & & & \\
\hline Businessperson & & & & 1 & 1 \\
\hline Civil servant & 3 & & & 2 & 5 \\
\hline Teacher & 1 & 1 & & & 2 \\
\hline Clerk/White-collar worker & 1 & 2 & & 2 & 5 \\
\hline Blue-collar worker & & & & 3 & 3 \\
\hline Retired & & & & 1 & 1 \\
\hline Student & 2 & 2 & 8 & & 12 \\
\hline Other & & 1 & & 1 & 2 \\
\hline Education & & & & & \\
\hline High school & & & & 2 & 2 \\
\hline Vocational college & & & & 1 & 1 \\
\hline 4 years of university & & & 8 & 5 & 13 \\
\hline Postgraduate or above & 7 & 6 & & 2 & 15 \\
\hline Personal monthly income: & & & & & \\
\hline RMB1,001-2,000 & & 2 & & & 2 \\
\hline RMB2,001-3,000 & & & & 1 & 1 \\
\hline RMB3,001-4,000 & & & & 2 & 2 \\
\hline RMB4,001-5,000 & & 1 & & 1 & 2 \\
\hline More than RMB5,000 & 2 & 1 & & 4 & 7 \\
\hline No income & 2 & 2 & 6 & & 10 \\
\hline Unstable income & 3 & & 2 & 2 & 7 \\
\hline Family size & & & & & \\
\hline 2-3 persons & 5 & 5 & 5 & 2 & 17 \\
\hline 4-5 persons & 2 & & 3 & 7 & 12 \\
\hline 6 or more persons & & 1 & & 1 & 2 \\
\hline
\end{tabular}


Figure 1: Five categories of attributes affecting the level of tourist satisfaction with theatrical performance in China.

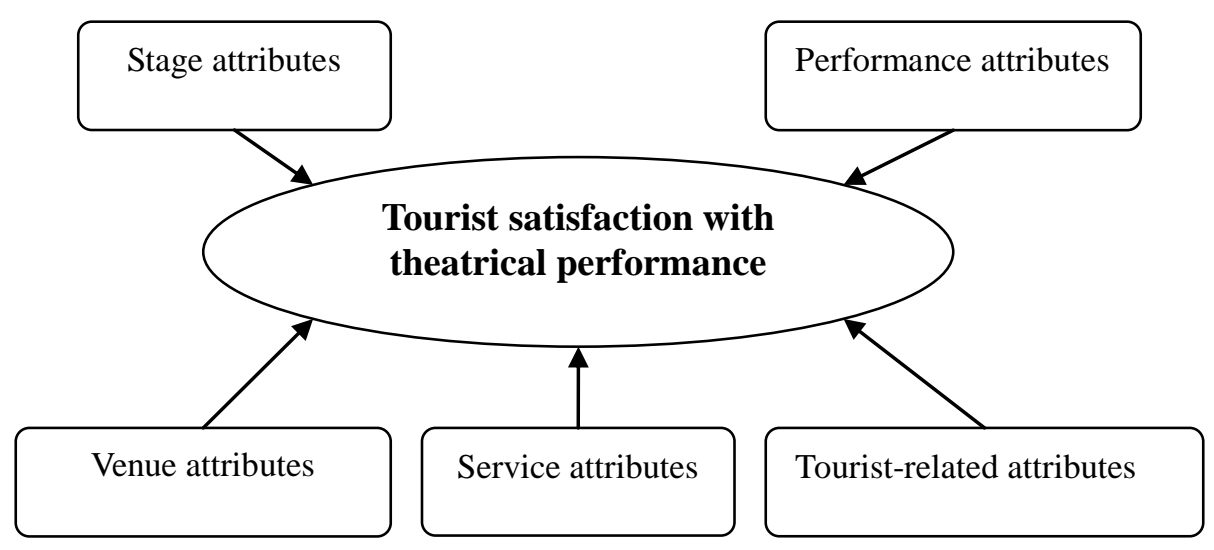


Table 2: Summary of nine stage attributes and related quotations

\begin{tabular}{|c|c|}
\hline Items & Quotations \\
\hline 1. Costumes & $\begin{array}{l}\text { The costumes of the performers were gorgeous } \\
\text { and unique. I really liked them, and you can only } \\
\text { find these kinds of costumes in this area. }\end{array}$ \\
\hline 2. Stage decoration & $\begin{array}{l}\text { I liked the traditional Chinese decorations in the } \\
\text { performance, such as the red lantern, and ethnic } \\
\text { decorations, which reflect the local culture or } \\
\text { traditional Chinese culture. }\end{array}$ \\
\hline 3. Background scenery or screen & $\begin{array}{l}\text { The background scenery or screen was beautiful } \\
\text { and impressive. During the performance, the } \\
\text { background changed, following the theme of the } \\
\text { different parts of the performance. }\end{array}$ \\
\hline \multirow[t]{2}{*}{ 4. Scale of the stage } & $\begin{array}{l}\text { I was shocked by the huge size of the stage, which } \\
\text { was just like that in the opening ceremony of the } \\
2008 \text { Olympic Games in Beijing. }\end{array}$ \\
\hline & $\begin{array}{l}\text { I don't care if the stage is large or small, I do care } \\
\text { about the content of the performance and size of the } \\
\text { stage being coordinated. }\end{array}$ \\
\hline 5. Water and a waterfall on the stage & $\begin{array}{l}\text { Suddenly, a waterfall appeared on the stage. That } \\
\text { was a big surprise to me... In the middle of } \\
\text { performance, drizzle suddenly fell from above the } \\
\text { audience, and we could feel the rain. }\end{array}$ \\
\hline 6. Smoke & $\begin{array}{l}\text { I did not like the heavy smoke because it hurt my } \\
\text { eyes. }\end{array}$ \\
\hline 7. Lighting & $\begin{array}{l}\text { The lighting of the performance was fantastic. I } \\
\text { was totally impressed by the magic lighting...The } \\
\text { lasers and fire during the performance were big } \\
\text { surprises to me. }\end{array}$ \\
\hline 8. Music and songs & $\begin{array}{l}\text { The music and songs were breathtaking... They } \\
\text { were created by famous musicians. }\end{array}$ \\
\hline 9. Loud sounds & $\begin{array}{l}\text { I did not like the loud sounds. They made me } \\
\text { uncomfortable. }\end{array}$ \\
\hline
\end{tabular}


Table 3: Summary of seven performing attributes and related quotations

\begin{tabular}{|l|l|}
\hline Items & Quotations \\
\hline 1. Performance is special and unique & $\begin{array}{l}\text { The performance should be special rather than } \\
\text { copying from others...I want to see an original } \\
\text { performance that demonstrates the local culture. }\end{array}$ \\
\hline 2. Professional performers & $\begin{array}{l}\text { The performance of the players should be } \\
\text { professional. We can guess whether the performers } \\
\text { are professional or amateur through their } \\
\text { performance. }\end{array}$ \\
\hline 3. Good coordination among performers & $\begin{array}{l}\text { Good performers demonstrate excellent work } \\
\text { through good coordination and cooperation with } \\
\text { others. }\end{array}$ \\
\hline 4. Performers show emotion & $\begin{array}{l}\text { Performers should perform with rapt attention and } \\
\text { express emotion. }\end{array}$ \\
\hline 5. Performers show enthusiasm & $\begin{array}{l}\text { They (performers) should also show enthusiasm } \\
\text { when performing. We could feel their enthusiasm } \\
\text { through their body language and facial expressions. }\end{array}$ \\
\hline 6. Good order of performance & $\begin{array}{l}\text { Every part of the performance should be scheduled } \\
\text { in good order. }\end{array}$ \\
\hline 7. Punctual start of performance & $\begin{array}{l}\text { A punctual start is important...I don't want to wait } \\
\text { along time. }\end{array}$ \\
\hline
\end{tabular}


Table 4: Summary of eleven venue attributes and related quotations

\begin{tabular}{|c|c|}
\hline Items & Quotations \\
\hline 1. Cleanliness of the venue & $\begin{array}{l}\text { The cleanliness of the venue could affect my level } \\
\text { of satisfaction to the performance. }\end{array}$ \\
\hline 2. Comfortable seating & $\begin{array}{l}\text { The comfortableness of the seats also plays an } \\
\text { important role... The theater should provide } \\
\text { comfortable seats to tourists. }\end{array}$ \\
\hline 3. Vision of the performance & $\begin{array}{l}\text { Vision of the performance also affects my } \\
\text { enjoyment of a theatrical performance. }\end{array}$ \\
\hline 4. Clean air & $\begin{array}{l}\text { The air conditioning was not good, and the quality } \\
\text { of the air was terrible. }\end{array}$ \\
\hline 5. Moderate temperature in the venue & $\begin{array}{l}\text { I watched The Romance of the Song Dynasty in the } \\
\text { summer of } 2008 \text {. The temperature in the venue was } \\
\text { really high, which made me uncomfortable. }\end{array}$ \\
\hline 6. Safety and security of the venue & $\begin{array}{l}\text { My family and I watched a theatrical performance } \\
\text { in Zhangjiajie, I found the theater to be of very } \\
\text { simple construction; therefore I worried about our } \\
\text { safety in the theater...I was so scared that it would } \\
\text { collapse. }\end{array}$ \\
\hline 7. Behavior of other audience members & $\begin{array}{l}\text { The behavior of other audience members affected } \\
\text { my level of satisfaction... Some spoke loudly, while } \\
\text { others took pictures although it was not allowed. } \\
\text { Some even stood up during the performance... All of } \\
\text { these kinds of bad behavior affected my feeling } \\
\text { about the theatrical performance. }\end{array}$ \\
\hline $\begin{array}{l}\text { 8. Suitable audience number in the } \\
\text { venue }\end{array}$ & $\begin{array}{l}\text { The audience number must be neither more nor } \\
\text { less in the performance... The small number of } \\
\text { tourists could affect the feeling of performers as well } \\
\text { as that of the tourists. The staff added even more } \\
\text { seats in the theater in case there were more tourist } \\
\text { arrivals...It was terrible...The theater was so } \\
\text { crowded. }\end{array}$ \\
\hline 9. Accessibility of the venue & $\begin{array}{l}\text { The transportation infrastructure in Lijiang is not } \\
\text { good. For The Impression of Lijiang, it's not easy to } \\
\text { get to the "theater." You need to hire a taxi to drive } \\
\text { for half an hour from the downtown area to the } \\
\text { venue... If I were on my own, I could not easily find } \\
\text { a car in the evening. }\end{array}$ \\
\hline 10. Location of the venue & $\begin{array}{l}\text { Some theatrical performances were located in } \\
\text { remote areas, far from my accommodation...In } \\
\text { particular, it is unsafe for individual tourists to be out } \\
\text { at night. }\end{array}$ \\
\hline 11. Weather & $\begin{array}{l}\text { The Impression of Lijiang was staged in a very } \\
\text { cold and windy amphitheater at } 3100 \text { meters... } \\
\text { Performances could be cancelled or postponed by } \\
\text { heavy rains or thick fog. } \\
\text { The bad weather could cause safety problem for } \\
\text { performers who might slip on the muddy stage... } \\
\text { would also feel terrible if the weather were cold or } \\
\text { there were heavy rain, because one watches the } \\
\text { performance out of doors. }\end{array}$ \\
\hline
\end{tabular}


Table 5: Summary of five service attributes and related quotations

\begin{tabular}{|l|l|}
\hline Items & Quotations \\
\hline 1. Service quality & $\begin{array}{l}\text { The quality of the service offered by the staff at } \\
\text { the venue affected my level of satisfaction... } \\
\text { Competent staff could answer my enquiry about the } \\
\text { theatrical performance; however, some of them did } \\
\text { not know much about the performance. }\end{array}$ \\
\hline 2. Ticket price/value for money & $\begin{array}{l}\text { The ticket price affected my level of satisfaction. } \\
\text { Some of the tickets were so expensive... It was not } \\
\text { value for money - when the performance ended, I } \\
\text { found that it wasn't worth it. }\end{array}$ \\
\hline 3. Performances are staged at night & $\begin{array}{l}\text { Theatrical performances are usually staged at } \\
\text { night. It was impossible for me after spending the } \\
\text { whole day at attractions to watch an evening } \\
\text { performance. }\end{array}$ \\
\hline 4. Suitable duration of the performance \\
$\begin{array}{l}\text { Most theatrical performances are put on in the } \\
\text { evening. I don't want to watch a long performance; I } \\
\text { just want to relax... Some lengthy theatrical } \\
\text { performances made me tired... I prefer a one-hour } \\
\text { performance. }\end{array}$ \\
\hline $\begin{array}{l}\text { Sale activities related to the the performance began, there were sales of } \\
\text { performance }\end{array}$ & $\begin{array}{l}\text { Before tha, Chinese paintings, and souvenirs... I did not } \\
\text { like these activities... Souvenir selling is irritating to } \\
\text { me. }\end{array}$ \\
\hline
\end{tabular}


Table 6: Summary of two tourist-related attributes and related quotations

\begin{tabular}{|l|l|}
\hline Items & Quotations \\
\hline $\begin{array}{l}\text { 1. Tourist understanding of the culture } \\
\text { being showcased by the performance }\end{array}$ & $\begin{array}{l}\text { I didn't completely understand The Impression of } \\
\text { Liusanjie... I am not familiar with the folk stories } \\
\text { and local culture of Guilin, which made it tough for } \\
\text { me to understand the performance. }\end{array}$ \\
\hline 2. Tourist companions & $\begin{array}{l}\text { The person who accompanies us also affects the } \\
\text { level of my satisfaction with the performance... If I } \\
\text { am not familiar with the local culture but my } \\
\text { companion knows the culture very well and explains } \\
\text { it to me, I will definitely know much more about the } \\
\text { production, and thus be more satisfied with it. }\end{array}$ \\
$\begin{array}{l}\text { If my family members didn't like it (the } \\
\text { performance) or were annoying to me. I would be } \\
\text { affected by them. }\end{array}$ \\
\hline
\end{tabular}

